\title{
Sport Sponsorship: The Relationship Between Team Loyalty, Sponsorship Awareness, Attitude Toward the Sponsor, and Purchase Intentions
}

\author{
Rui Biscaia, Abel Correia, and Antonio Fernando Rosado \\ Technical University of Lisbon \\ Stephen D. Ross \\ University of Minnesota \\ João Maroco \\ Higher Institute of Applied Psychology (ISPA-IUL), Lisbon
}

\begin{abstract}
Sponsorship studies have generally been focused on attitudinal measures of fan loyalty to understand the reactions to abstract sponsors. This study examines the relationships between both attitudinal and behavioral loyalty with sponsorship awareness, attitude toward two actual sponsors, and purchase intentions. Data were collected among fans of a professional soccer team, and the results of a structural equation model provide evidence that attitudinal loyalty impacts the attitude toward both sponsors and purchase intentions. Behavioral loyalty influences sponsorship awareness, and impacts differently the attitude and purchase intentions toward each sponsor. Sponsorship awareness influences significantly the attitude toward both sponsors, while the attitude toward the sponsor was the strongest predictor of purchase intentions. These findings highlight the importance of examining actual sponsors and suggest managerial implications, such as the need for sponsors to help attract fans to the stadium and to design additional activation strategies to improve sponsorship value.
\end{abstract}

Corporate sport sponsorship has been growing in popularity worldwide over the past several decades, moving from a philosophy of corporate donation to a key element of marketing strategy used by major corporations to create brand value and obtain a competitive advantage in the marketplace (Henseler, Wilson, \& Westberg, 2011). According to the International Events Group (IEG, 2012), the worldwide sponsorship market was estimated at $\$ 48.6$ billion in 2011, with approximately $68 \%$ of the total money being invested in sport properties. A total of $\$ 12.4$ billion was spent in sport sponsorship in North America during that period (IEG, 2012), while sponsorship in the

Rui Biscaia is with the Centro Interdisciplinar de Estudo da Performance Humana (CIPER), Faculdade de Motricidade Humana, Universidade Técnica de Lisboa, Portugal. Abel Correia is with the Centro Interdisciplinar de Estudo da Performance Humana (CIPER), Faculdade de Motricidade Humana, Universidade Técnica de Lisboa, Portugal. Stephen D. Ross is with the Department of Sport Management, University of Minnesota, Minneapolis, Minnesota, United States. Antonio Fernando Rosado is with the Faculdade de Motricidade Humana, Universidade Técnica de Lisboa, Portugal. João Maroco is with the ISPA-Instituto Universitário, Lisboa, Portugal.
European soccer market was estimated to be $\$ 20.9$ billion in the 2010-2011 season (Deloitte, 2012a). In light of this growth and widely formalized practice, sport sponsorship represents an important marketing tool for corporate sponsors and a valuable income stream for professional sport teams (Bühler, Hefferman, \& Hewson, 2007). Irwin and Asimakopoulos (1992) suggested that sponsors are more attracted to invest in sport teams with a strong bond with their fans, given that goodwill toward the team can be transferred to the sponsors' brands or products (Madrigal, 2001).

Recent empirical studies have examined the role of fans' psychological attachment to their teams on pivotal reactions to the sponsors, such as sponsorship awareness (Ko, Kim, Claussen, \& Kim, 2008; Lee, Harris, \& Lyberger, 2011), attitude toward the sponsor and purchase intentions (Gwinner \& Bennett, 2008; Hong, 2011). The concept of psychological attachment is often discussed in the sports literature as a means to capture the attitudinal component of team loyalty (Bauer, Stokburger-Sauer, \& Exler, 2008; Iwasaki \& Havitz, 2004; Neale \& Funk, 2006). However, to fully understand the concept of team loyalty it is important to measure both the attitudinal and behavior components (Kaynak, Salman, \& Tatoglu, 2008), yet the role of this multidimensional construct 
on sponsors' reactions has not been studied. In addition, sport fans may have varying attitudes and intentions toward different companies, and past research has focused primarily on the evaluation of abstract corporate sponsorship rather than on actual team sponsors (Madrigal, 2001; Hong, 2011). Thus, this study was designed to understand the role of team loyalty on the reactions to actual sponsors of a team. Specifically, the purpose of this study was to examine the relationship between both attitudinal and behavioral components of team loyalty with sponsors' awareness, attitude toward actual sponsors, and purchase intentions.

\section{Literature Review and Hypothesis Development}

\section{Sport Sponsorship}

Sponsorship activities in the sports context represent an important stream of research in the marketing literature, and sponsorship can be defined as "an investment, in cash or in kind, in an activity, in return for access to the exploitable commercial potential associated with that activity" (Meenaghan, 1991, p. 36). In line with this definition, researchers commonly accept that sponsorship can be viewed as a business-to-business relationship between a sponsor and a sport entity for mutual benefits (Farrelly, Quester, \& Greyser, 2005; Henseler et al., 2011). This perspective implies that a sport entity earns the monetary support and/or other in-kind resources needed to improve team quality and other managerial aspects of the club, while the sponsor obtains the tangible and intangible benefits of being associated with the sport entity (Chen \& Zhang, 2011; Yang, Sparks, \& $\mathrm{Li}, 2008)$. There are a number of objectives and benefits that corporations pursue when activating sport sponsorship programs. For example, benefits may be related with overcoming cultural barriers (Cousens, Babiak, \& Bradish, 2006), establishing relationships with media corporations (Chadwick \& Thwaites, 2004), becoming involved with the community, increasing brand awareness and facilitating positive brand image, reaching new target markets, boosting sales and market share through brand loyalty, protect against competitors, obtaining hospitality opportunities (Apostolopoulou \& Papadimitriou, 2004), and even improving employee morale or facilitating staff recruitment (Barros \& Silvestre, 2006). In essence, sport sponsorship has become a powerful marketing strategy used by firms to communicate with vast external and internal audiences to differentiate themselves from its competitors (Cornwell, 2008), with the ultimate goal to orienting consumer's preferences toward sponsors' products (Barros \& Silvestre, 2006).

A firm's engagement in a sport sponsorship arrangement heightens both brand exposure and access to its products among sport fans, providing the opportunity to bring previously distant stakeholders into close proximity (Cunningham, Cornwell, \& Coote, 2009). Past research has shown that fans are emotionally involved when attending sporting events (Biscaia, Correia, Rosado, Maroco, \& Ross, 2012; Kwak, Kim, \& Hirt, 2011; Madrigal, 2003), and global brands use this emotional impact of sport to connect with the consumers (Santomier, 2008). Furthermore, Meenaghan (2001) suggests that sponsor's investment in professional sport teams generates a goodwill effect among fans, which in turn influences their attitudes and behaviors toward the sponsor. Similarly, Parker and Fink (2010) contend that once the relationship between team and sponsor is established, the sponsor becomes a member of a tight network of fans. To that extent, it is crucial to understand the role of team loyalty on fans' evaluation of corporate sponsors (Hong, 2011).

\section{Actual Sponsors in Professional Sport}

Sport fans are regularly exposed to multiple sponsors from different industries (Chavanat, Martinent, \& Ferrand, 2009), given that sport teams represent important vehicles used by firms to heighten relationships with target audiences (Bühler et al., 2007; Henseler et al., 2011). As such, the use of actual sponsors associated with professional teams should be a focal point in sponsorship research. Previous studies suggest that sponsors want to observe sport fans having the same positive reactions regarding the sponsorship brands as they have toward their team (Madrigal, 2001; Shaw \& McDonald, 2006). However, fans' responses to sponsorship activities may differ due to the knowledge structures they possess (Roy \& Cornwell, 2004). For example, Wakefield and Bennett (2010) suggest that market prominence of the brand and its relatedness with the team/event are important aspects in determining how consumers respond to the sponsorship. Similarly, Speed and Thompson (2000) mention that sponsors perceived as being sincere will achieve better responses compared with those who are engaged in a large number of sponsorship deals. Drawing on these views, it is important to understand the role of team loyalty on fans' reactions to actual sponsors of the team, and verifying if differences occur according to the sponsoring brands. To that extent, the current study is focused on the examination of actual sponsors of a team, and compares the strength of the relationships between team loyalty and fans' reactions for each sponsor. In doing so, this study seeks to contribute to a better understanding of the benefits of sponsorship activities for both the sport entities and corporate sponsors.

\section{Team Loyalty}

The literature refers to customer loyalty as a favorable attitude and consistent purchase behavior toward a particular brand (Wilkie, 1994), which can be interpreted as a function of perceived product superiority, social bonding and their synergic effect (Oliver, 1997). In the sports context, team loyalty represents a form of psychological connection to a team resulting in consistent and enduring positive behaviors and attitudes toward a team (Funk \& 
James, 2001). Numerous scholars have agreed that the loyalty construct should include both attitudinal and behavioral dimensions (Bauer et al., 2008; Bee \& Havitz, 2010; Bodet \& Bernache-Assollant, 2011; Kaynak et al., 2008). Behavioral loyalty refers to the actual purchase behavior toward the team (Stevens \& Rosenberger, 2012), and can include aspects such as the frequency of game attendance during a season or over time, the regularity in following the team through media, and the money spent in merchandise (Bodet \& Bernache-Assollant, 2011). Alternatively, attitudinal loyalty is a function of psychological processes including the commitment and attitudinal preference of a person toward the team (Bauer et al., 2008; Kaynak et al., 2008).

The most common measures of attitudinal loyalty in sponsorship studies are fan involvement and team identification (Alexandris, Douka, Bakaloumi, \& Tsasousi, 2008; Chen \& Zhang, 2011). Fan involvement refers to the perceived interest and personal importance of a sport activity to an individual (Ko et al., 2008; Shank \& Beasley, 1998), while team identification represents the extent to which a fan believes the team is an extension of his or herself (Theodorakis, Wann, \& Weaver, 2012; Wann, Melnick, Russell, \& Pease, 2001). These constructs refer to a process of psychological link that reflects an individual's commitment to the team. However, attitudinal loyalty should capture both the tendency to be loyal (i.e., commitment) and the attitude toward the act of purchasing the brand (Kaynak et al., 2008; Stevens \& Rosenberger, 2012), to provide a better understanding of actual purchase behaviors (Park \& Kim, 2000). A loyal behavior is often related to a strong attitude toward the team, yet the games may be attended because the person was offered a season-ticket (Bauer et al., 2008). As such, true loyalty only exists when a consumer regularly purchases the product and displays a strong attitudinal disposition toward a particular brand and its products (Caruana, 2002; Kaynak et al., 2008). Therefore, the conceptualization of team loyalty in the current research is focused on both attitudinal and behavioral dimensions as a way to better understand the correspondence of actual and future behaviors of the fans toward their team (Bodet \& Bernache-Assollant, 2011; Kaynak et al., 2008). Drawing upon this view, the following hypothesis is proposed:

$\mathrm{H} 1$ : Attitudinal loyalty has a direct positive effect on behavioral loyalty.

Previous literature suggests that the link between a consumer and his/her favorite team plays an important role on sponsorship reactions. That is, fans with a stronger devotion to a team tend to have more knowledge about the event's environment, and thus, are more likely to discriminately process the sponsorship information (Roy \& Cornwell, 2004; Wakefield \& Bennett, 2010). For example, Maxwell and Lough (2009) reported that the level of team identification and the number of home games attended was crucial to ensure correct sponsor recognition, while Ko et al. (2008) found that consumers' involvement with the sporting event was positively related to sponsorship awareness. Despite the contribution of these studies to the continued understanding of fans' reactions to sponsors, limitations suggest the need for further research. Specifically, previous studies do not capture the correspondence of attitudes-behaviors toward the team, which is pivotal when studying the loyalty concept (Kaynak et al., 2008) and its consequences. Thus, in the current study it is hypothesized that:

$\mathrm{H} 2_{\mathrm{a}}$ : Attitudinal loyalty has a direct positive effect on sponsorship awareness.

$\mathrm{H} 2_{\mathrm{b}}$ : Behavioral loyalty has a direct positive effect on sponsorship awareness.

Parker and Fink (2010) and Hong (2011) maintain that being a fan of a team contributes positively to the attitude toward the sponsors, given that the goodwill that fans feel toward the team can be transferred to the sponsoring brand via team-sponsor association (Madrigal, 2001). However, both studies used abstract sponsors, rather than actual sponsors of the team. This gap is addressed in other studies highlighting that the attitudes toward actual sponsors are influenced by consumers' identification with the team or sport (Gwinner \& Bennett, 2008; Schlesinger \& Güngerich, 2011). Notwithstanding, research incorporating both attitudes and behavior directed toward the team is important to better understand fans' attitudes toward actual team sponsors. As such, the following hypotheses are proposed:

$\mathrm{H} 3_{\mathrm{a}}$ : Attitudinal loyalty has a direct positive effect on attitude towards actual sponsors.

$\mathrm{H} 3_{\mathrm{b}}$ : Behavioral loyalty has a direct positive effect on attitude towards actual sponsors.

The gaps mentioned above are also evident in studies designed to understand the intentions to purchase sponsors' products. For example, Ko et al. (2008) noted that consumers' involvement with the sport had a significant role on purchase intentions toward generic sponsors' products, while Lee et al. (2011) suggest that sport consumers with higher attendance frequency are more likely to buy products from generic sponsors of an event. These studies are based on the idea that the stronger the link with the team, the more the fans might feel it is their duty to purchase the sponsors products as a way to repay the sponsoring brands for supporting the team (Crimmins \& Horn, 1996). Based on previous literature regarding sport sponsorship and remaining limitations, it is hypothesized here that:

$\mathrm{H} 4_{\mathrm{a}}$ : Attitudinal loyalty has a direct positive effect on intentions to purchase products of actual sponsors.

$\mathrm{H} 4_{\mathrm{b}}$ : Behavioral loyalty has a direct positive effect on intentions to purchase products of actual sponsors. 


\section{Sponsorship Awareness}

The awareness of a sponsor is a widely accepted mechanism used for accessing the effectiveness of a sponsorship program (Miloch \& Lambrecht, 2006; Walsh, Kim, \& Ross, 2008). A solid awareness of a sponsor is crucial to increase brand equity (Keller, 1993) and to avoid the ambush marketing tactics of competitors (O'Reilly, Nadeau, Séguin, \& Harrison, 2007). The concept of brand awareness refers to a consumer's ability to identify the brand under different conditions, and consists of brand recall and brand recognition performance (Keller, 1993). According to Aaker (1996), brand recall is related to the consumer's ability to retrieve from memory the brand name without any mention of product category or other brands, while brand recognition (also termed as 'aided recall') relates to the consumer's ability to remember past exposure to a brand when provided brand cues.

Crompton (2004) refers to sponsorship awareness as being the first stage in the sequence of sponsorship benefits, because to be effective with target audiences, sponsorship must first be known to exist (Farrelly et al. 2005). That is, if awareness is not first achieved, sponsors cannot meet their subsequent objectives. O'Reilly et al. (2007) state that brand awareness is critical to achieving broader strategic objectives since consumers may feel better about the brand because of the effect triggered through exposure inside the stadium. In line with this view, recent studies have emphasized that sponsorship awareness is an important component in consumers' attitudes toward the sponsors and purchase intentions (Ko et al., 2008; Schlesinger \& Güngerich, 2011). However, the consequences of sponsorship awareness have not been empirically examined in studies using actual sponsors of the teams, which is crucial in understanding how sport sponsorship works in the mind of the consumer. Thus, we propose in the current paper that:

H5: Sponsorship awareness has a direct positive effect on attitude towards actual sponsors.

H6: Sponsorship awareness has a direct positive effect on intentions to purchase products of actual sponsors.

\section{Attitude Toward the Sponsor}

The development of a favorable attitude toward the sponsor is suggested in the literature as a pivotal factor for sponsorship effectiveness (Alexandris, Tsaousi, \& James, 2007; Chen \& Zhang, 2011; Speed \& Thompson, 2000), and the theory of planned behavior (Ajzen, 1991) provides an important theoretical foundation to this notion. According to Ajzen (1991), an attitude toward an object plays a significant role in predicting a person's behavioral intentions and can affect a behavioral response to the object (Ajzen, 2001). An attitude is often defined as a "psychological tendency that is expressed by evaluating a particular entity with some degree of favor or disfavor" (Eagly \& Chaiken, 1993, p.1), and attitudes can be formed through direct experiences with an entity or exposure to knowledge and messages (Albarracin, Johnson, \& Zanna, 2005). A person's beliefs about an object represent the basis of his/her attitude toward that object, with beliefs being viewed as the linkages between an attitude-object and its attributes, characteristics, outcome, goal, or value (Fishbein \& Ajzen, 1975). Keller (2003) supports the idea that attitude toward the sponsor represents the consumer's overall evaluation of a brand sponsoring an event, and Meenaghan (2001) operationalized this construct as a favorable disposition toward the sponsor.

Firms engaging in sponsorship activities are expecting to see sport consumers having the same positive feelings regarding sponsorship brand as they have toward their team (Shaw \& McDonald, 2006), and sport consumers tend to have favorable attitudes toward the sponsor if they believe that the sponsorship is important to the team (Madrigal, 2001; Cornwell, Humphreys, Maguire, Weeks, \& Tellegen, 2006). Alexandris et al. (2007) further suggest that the sponsor's favorability and transfer of goodwill are the specific consumer attitudes that are targeted with sponsorship activities, and past research has suggested that attitude toward the sponsor is an important predictor of purchase intentions (Koo, Quarterman, \& Flynn, 2006; Speed \& Thompson, 2000). Still, most research is focused on abstract sponsors (e.g., Speed \& Thompson, 2000) and little is known about how the attitude toward the actual specific sponsors influences the intention to purchase products of that sponsor. Therefore, following on the propositions of previous research, it is hypothesized that:

H7: Attitude towards the sponsor has a direct positive effect on intentions to purchase products of that sponsor.

\section{Purchase Intentions}

From a sponsor's perspective, consumer purchase intention is the most useful indicator of sponsorship effectiveness given its impact on future sales (Crompton, 2004). In addition, the intent to purchase sponsors' products is a focal indicator for sport entities to legitimatize their relationships with actual sponsors and to negotiate future sponsorship contracts (Hong, 2011). Purchase intentions are not the same as actual purchase behaviors, yet consumers' intentions are vital in guiding their behaviors (Ajzen, 2001). According to Spears and Singh (2004), purchase intentions refer to the person's conscious plan in exerting an effort to purchase a brand. Consistent with this proposition, Dees, Bennett, and Villegas (2008) suggest that purchase intentions represent an indicator of an individual's motivation to make a specific purchase behavior.

According to Meenaghan (2001), a fan's response to the sponsors passes through a series of stages, from first becoming aware of the sponsors to finally adopting purchase intentions and behaviors toward their products. Fans' awareness of the sponsors contributes positively to attitude toward the sponsor, and purchase intention 
is subsequent to that positive attitude (Schlesinger \& Güngerich, 2011). When fans see sponsors supporting their team, they may buy the sponsors' products as an extension of goodwill or to repay the sponsor for supporting the team (Parker \& Fink, 2010). Having this continuum of outcomes in consideration, several studies have used purchase intentions as the final indicator to evaluate sponsorship effectiveness (e.g., Alexandris et al., 2007; Madrigal, 2001). However, most studies refer to generic sponsors, rather than focusing on actual sponsors associated with a team (Hong, 2011). Thus, the current study considers purchase intentions as the endpoint of sponsorship effectiveness to understand the relationship between team loyalty and fans' evaluation of actual sponsors of professional team sports. The hypothesized model guiding this research is presented in Figure 1.

\section{Method}

The current research was conducted in the setting of the top Portuguese soccer league, with the team Sport Lisboa e Benfica (SLB) and two of its main sponsors. Henseler et al. (2011) maintain that the higher ranking of the league in which the team is playing, the higher the appeal of the sponsorship. The top Portuguese soccer league consists of sixteen teams, and in 2011 was ranked as the fourth best league in the world by the International Federation of Football History and Statistics (Bola, 2012). In addition, the SLB's history consists of several national and international titles, with the team enjoying enormous fan support. For example, SLB has been acknowledged as the soccer club with the largest number of paid-up members in the world (Guinness World Records, 2007), with the average attendance at home games during the 2011-2012 season being over 40,000 spectators per game. Further evidence of the club's popularity is provided by the fact that it owns a club TV channel, and was one of top clubs in Europe in overall revenues during 2011 (Deloitte, 2012b).

Sport teams rely on numerous sponsorship sources, and one of the major attractions of sport sponsorship for a corporation is the opportunity to display a brand name or logo on the team shirts (Chadwick \& Thwaites, 2004). At time of data collection, SLB had twelve official sponsors, and the two sponsors appearing on the team shirt were selected for this study. These sponsors have had contracts with SLB since 2004 and in addition to the logo on team shirt, each sponsor has naming rights in one of the stadium's stands. Still, these sponsors differ in terms of product-category, specifics of the partnership deal, and market prominence. Due to proprietary information and to ensure anonymity, the sponsors in this study are referred to as Sponsor A and Sponsor B. Sponsor A is an alcoholic beverage brand and has no sponsorship deals with other Portuguese soccer teams. This brand was a leader in the Portuguese market during 2011, enjoying about $46 \%$ of market share and developing an increased presence in international markets (Económico, 2012). In turn, Sponsor B is a television and internet-service provider, which has sponsorship deals with the two major rival soccer teams of the league. In terms of market share, this brand occupied the second position in its segment during 2011, with about half of subscribers than the market leader (Jornal de Negócios, 2011).

\section{Participants and Data Collection}

Data were collected through a mail survey with the support of the SLB marketing personnel. The mail survey was sent to 4000 supporters randomly selected from SLB's database with 2068 surveys being returned. After data screening, 1834 surveys were deemed usable for data analysis for an effective response rate of $45.85 \%$.

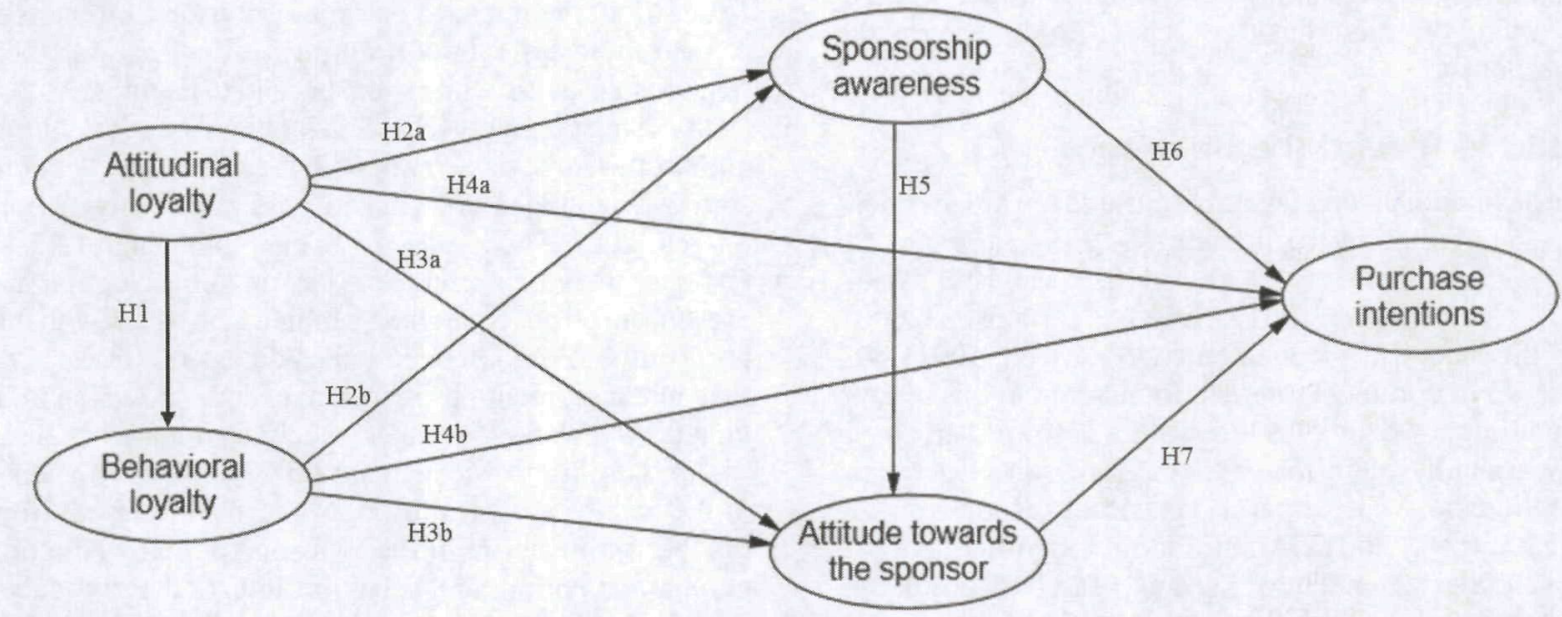

Figure 1 - Hypothesized model. 
It is important to note that the use of mail surveys commonly allows for collecting large samples within a short period of time, but it may limit the representativeness of the sample. Ages of the respondents ranged from 16 to 70 years $(M=31.92$ years), and about two-thirds were in the $20-40$ age bracket (65.6\%). A great majority were males $(87.7 \%)$ and almost half reported going to the stadium in the company of two or three other persons $(47.8 \%)$. The majority of respondents were paid-up members of the team $(85.9 \%$ ), paying a monthly fee to have discounts on club's activities, yet only about one-third were season-ticket holders (25.5\%). Nearly two-thirds of the respondents indicated paying the necessary fee for accessing the TV channel of the club (63.4\%), while almost half responded watching more than 20 home and away games of the team each season on either public or private TV channels $(47.8 \%)$.

\section{Measures}

The mail survey included items adopted from previous literature to assess team loyalty, sponsorship awareness, attitude toward the sponsors, and purchase intentions, in addition to social and demographic questions (see Table 1). All measurement items were translated into Portuguese and back-translated into English to ensure the accuracy between the original scales and the necessary translated versions (Banville, Desrosiers, \& Genet-Volet, 2000).

Team Loyalty. Team loyalty was measured using both attitudinal and behavioral constructs, with attitudinal loyalty including five items to capture both the commitment with the team and behavioral intentions (Kaynak et al., 2008). Three of these items were derived from Biscaia et al. (2012) to gauge behavioral intentions,

\section{Table 1 Factor Loadings, Z-Values, Composite Reliability (CR), and Average Variance}

\section{Extracted (AVE)}

\begin{tabular}{|c|c|c|c|c|c|c|}
\hline \multirow[b]{2}{*}{ Constructs/items } & \multicolumn{3}{|c|}{ Sponsor A } & \multicolumn{3}{|c|}{ Sponsor B } \\
\hline & Loading & CR & AVE & Loading & CR & AVE \\
\hline Attitudinal Loyalty & & .71 & .45 & & .71 & .45 \\
\hline I intend to attend future games of <team name> & .732 & & & .732 & & \\
\hline I would likely recommend <team name $>$ games to other people & .672 & & & .672 & & \\
\hline I intend to purchase other products and services of <team name $>$ & .600 & & & .600 & & \\
\hline I would be willing to defend $<$ team name $>$ publicly, even if it caused controversy (a) & & & & & & \\
\hline I would watch <team name> games regardless of which team they were playing (a) & & & & & & \\
\hline Behavioral Loyalty & & .88 & .72 & & .88 & .72 \\
\hline Number of <team name $>$ games attended per season & .932 & & & .932 & & \\
\hline Number of <team name > games attended in the current season & .965 & & & .965 & & \\
\hline Length in years as a season-ticket holder to the $<$ team name $>$ games & .600 & & & .600 & & \\
\hline Attitude toward the sponsor & & .95 & .85 & & .97 & .91 \\
\hline I like the <sponsor name> brand & .930 & & & .952 & & \\
\hline$<$ Sponsor name $>$ is a very good brand of $<$ product-category $>$ & .929 & & & .965 & & \\
\hline I have a favorable disposition toward <sponsor name $>$ & .911 & & & .952 & & \\
\hline Purchase Intentions & & .93 & .77 & & .95 & .82 \\
\hline I would buy <product-category $>$ from $<$ sponsor name $>$ & .846 & & & .887 & & \\
\hline $\begin{array}{l}\text { Next time I need to buy a <product-category }>\text {, I would consider buying } \\
<\text { sponsor name> }\end{array}$ & .974 & & & .957 & & \\
\hline $\begin{array}{l}\text { The <sponsor name }>\text { sponsorship to <team name }>\text { makes me more likely to buy } \\
<\text { product-category }>\text { from this brand }\end{array}$ & .716 & & & .796 & & \\
\hline $\begin{array}{l}\text { I would be more likely to buy < product-category }>\text { of }<\text { sponsor name }>\text { over } \\
\text { its competitors }\end{array}$ & .951 & & & .964 & & \\
\hline
\end{tabular}

Note. ${ }^{(a)}$ Item eliminated due the lack of individual reliability.

Model fit (sponsor A): $\chi^{2}(59)=520.23(\mathrm{p}<.001), \chi^{2} / \mathrm{df}=8.82, \mathrm{TLI}=.97, \mathrm{CFI}=.98, \mathrm{GFI}=.96, \mathrm{RMSEA}=.07$.

Model fit (sponsor B): $\chi^{2}(68)=290.58(\mathrm{p}<.001), \chi^{2} / \mathrm{df}=4.93$, TLI= $.99, \mathrm{CFI}=.99, \mathrm{GFI}=.98, \mathrm{RMSEA}=.05$. 
while two items regarding to fans' commitment with the team were adopted from Neale and Funk (2006). All items were measured on a 7-point Likert-type scale ranging from 'Strongly Disagree' (1) to 'Strongly Agree' (7). Behavioral loyalty consisted of three items derived from Bodet and Bernache-Assollant (2011) to assess actual and past behaviors, and responses to these items were open-ended.

Sponsorship Awareness. Recall and recognition measures were used to assess sponsorship awareness (Walsh et al., 2008). Participants were asked to name, without any cues, the official sponsors of SLB to assess recall. Responses were scored from 0 to 12 based on the number of sponsors recalled correctly. Next, a list of twelve brand names including six true sponsors and six nonsponsors was used to assess recognition. Responses were also scored from 0 to 12 , but were based on the number of brand names correctly identified as being sponsors by the participants. The recall measure was administered first to avoid contagion of the recognition measure by brand names being first showed to the participants.

Attitude Toward the Sponsor. The three-item scale proposed by Gwinner and Bennett (2008) was used to assess the attitude toward the two sponsors of the team. Participants were asked to rate their impressions regarding each sponsor on a 7-point Likert-type scale, anchored by 'Strongly Disagree' (1) and 'Strongly Agree' (7).

Purchase Intentions. This construct included the two items proposed by Gwinner and Bennett (2008), and two additional items derived from Hong (2011) to increase construct reliability. Participants responded to these items for each of the sponsors and also used a 7-point Likert-type scale, anchored by 'Strongly Disagree' (1) and 'Strongly Agree' (7).

\section{Data Analysis}

Data were analyzed using AMOS 20.0, and a two-step maximum likelihood structural equation model (SEM) was performed. First, a confirmatory factor analysis (CFA) was conducted to assess the measurement model for each sponsor. Internal consistency of the constructs was measured through composite reliability (Hair, Black, Babin, \& Anderson, 2009). Convergent validity was evaluated through the average variance extracted (AVE), while discriminant validity was established when AVE for each construct exceeded the squared correlations between that construct and any other (Fornell \& Larcker, 1981). Second, the SEM was estimated for each sponsor to test research hypotheses. Goodness of fit for both the measurement and structural models was assessed with the ratio of chi-square $\left(\chi^{2}\right)$ to its degrees of freedom, Tucker-Lewis Index (TLI), comparative-of-fitindex (CFI), goodness-of-fit index (GFI), and root mean square error of approximation (RMSEA). In addition, a multigroup analysis was performed to verify if the path coefficients for the hypotheses differ among the models for Sponsor A and B. The model's invariance was tested by comparing the unconstrained model with the model constraining the structural weights (Loehlin, 2003). The significance of the structural weights was evaluated using the Z-tests produced by AMOS and statistical significance was assumed at a .05 level.

\section{Results}

\section{Measurement Model}

The skewness values for the items used in this study ranged from $-2.18-2.38$, while the kurtosis values ranged from -1.41-5.55. According to Kline (1998), these values do not represent nonnormality problems that may limit further use in factor analysis. After this initial analysis, the measurement model was analyzed for each sponsor separately. The results of the CFA in the model for both Sponsor A and B showed that the factor loadings of two items from attitudinal loyalty failed to exceed the cut-off point of .50 (Hair et al., 2009), and consequently, were eliminated in both models (Table 1). The final 3-item content of this construct is consistent with the idea that attitudinal loyalty provides information about future behavior, while behavioral loyalty reflects the current or historical situation (Aspinall, Nancarrow, \& Stone, 2001). In addition, construct validity of sponsorship awareness was not accepted given that the values of composite reliability (.43) and AVE (.23) were below the recommended criteria of .70 and .50 , respectively (Fornell \& Larcker, 1981; Hair et al., 2009). Based on these results and prior research suggesting that recall tasks are more accurate than recognition tasks when assessing sponsorship awareness (Cornwell, 2008; Ko et al., 2008; Stotlar, 1993), the recall measure was selected for the final model. After these procedures, all items showed high factor loadings, ranging from .505 to .974 (Sponsor A), and from .501 to .965 (Sponsor B), providing evidence that each item appropriately captured their respective factor. As shown in Table 1 , the composite reliability values were above the recommended .70 threshold in both models (Hair et al., 2009), ranging from .71 to .95 (Sponsor A) and from .71 to .97 (Sponsor B), indicating that the constructs were internally consistent. All AVE values were close to or greater than the .50 standard for convergent validity (Fornell \& Larcker, 1981), ranging from .45 to .85 (Sponsor A), and from .45 to .91 (Sponsor B).

Descriptive statistics of the measures used in both models and its correlations are reported in Table 2. It is important to note that a great majority of the respondents recalled both sponsors (Sponsor A: 85.1\%; Sponsor B: $75.5 \%$ ). In addition, the mean scores for the constructs related to the two sponsors showed that respondents have a better attitude $(\mathrm{M}=5.88 ; S D=1.31)$, as well as higher purchase intentions $(M=5.10 ; S D=1.93)$ toward Sponsor A. Discriminant validity of the measures was 
accepted given the squared correlations between each construct and any other were lower than the AVE values for each construct in the two models. Furthermore, the results of the final measurement model using Sponsor $\mathrm{A}\left[\chi^{2}(59)=520.23(p<.001), \chi^{2} / \mathrm{df}=8.82, \mathrm{TLI}=.97\right.$, $\mathrm{CFI}=.98, \mathrm{GFI}=.96, \mathrm{RMSEA}=.07]$ and Sponsor $\mathrm{B}$ $\left[\chi^{2}(68)=290.58(p<.001), \chi^{2} / \mathrm{df}=4.93, \mathrm{TLI}=.99, \mathrm{CFI}\right.$ $=.99, \mathrm{GFI}=.98, \mathrm{RMSEA}=.05]$ showed an acceptable fit to the data. The $\chi^{2}$ value was significant and its ratio to the degrees of freedom was above the 3.0 criterion (Kline, 1998) for both models. However, it is important to consider other fit indices since the $\chi^{2}$ statistic has been shown to be sensitive to sample size (Hair et al., 2009), and this study was conducted with a large sample $(n=$ 1834). The TLI, CFI, and GFI values in both models were greater than the recommended threshold of .90 (Hair et al., 2009) providing evidence of good fit. In addition, RMSEA was within the criteria of .08 for acceptable fit in the model for Sponsor A, and it was less than .06 in the model with Sponsor B suggesting good fit (Byrne, 2000). Overall, the measurement model for each sponsor showed an acceptable fit to the data, and consequently, the structural model was examined.

\section{Structural Model}

The examination of the structural model included a test of the overall model fit as well as individual tests of the relationships among the latent constructs. The overall assessment of the structural models was found to be acceptable for both models using Sponsor $\mathrm{A}\left[\chi^{2}(68)=\right.$ $550.45(p<.001), \chi^{2} / \mathrm{df}=8.01, \mathrm{TLI}=.97, \mathrm{CFI}=.98, \mathrm{GFI}$ $=.96$, RMSEA $=.06]$ and Sponsor B $\left[\chi^{2}(68)=294.90\right.$ $(p<.001), \chi^{2} / \mathrm{df}=4.34(p<.001), \mathrm{TLI}=.99, \mathrm{CFI}=.99$, $\mathrm{GFI}=.98, \mathrm{RMSEA}=.04]$. The path coefficients for each model are illustrated in Table 3, indicating that not all hypotheses were supported. Attitudinal loyalty showed a significant positive effect on behavioral loyalty $(\beta=.38$, $p<.01)$ in both models, which supports H1. The effect of attitudinal loyalty on sponsorship awareness was not significant in both models $(p>.05)$, and consequently $\mathrm{H} 2_{\mathrm{a}}$ was not confirmed. Conversely, behavioral loyalty $(\beta=.09, p<.01)$ showed a significant positive effect on sponsorship awareness in both models providing support to $\mathrm{H} 2_{\mathrm{b}}$. The relationships between attitudinal loyalty and attitude toward the sponsor were significant for both sponsors (Sponsor A: $\beta=.22, p<.01$; Sponsor B: $\beta=.17, p<$ .01) confirming $\mathrm{H} 3_{\mathrm{a}}$. In contrast, behavioral loyalty was not significant in predicting attitude toward the Sponsor $\mathrm{A}(p>.05)$, and showed a significant negative effect regarding Sponsor B $(\beta=-.10, p<.01)$, therefore, $\mathrm{H}_{\mathrm{b}}$ was not supported. The path coefficients between attitudinal loyalty and purchase intentions were significant for both Sponsor A $(\beta=.08, p<.01)$ and Sponsor B ( $\beta$ $=.07, p<.01$ ) providing support for $\mathrm{H} 4_{\mathrm{a}}$. Hypothesis $4_{\mathrm{b}}$ was partially confirmed as the effect of behavioral loyalty on purchase intentions was significant for Sponsor A ( $\beta$ $=.08, p<.01$ ), while it was not significant for Sponsor B $(p>.05)$. Sponsorship awareness showed a positive significant effect on attitude toward both Sponsor $\mathrm{A}(\beta=$ $.09, p<.01)$ and Sponsor B $(\beta=.09, p<.01)$ confirming H5. However, H6 was not supported given that the path

Table 2 Mean $(M)$, Standard Deviation (SD), and Correlation Matrix

\begin{tabular}{|c|c|c|c|c|c|c|c|}
\hline \multirow[b]{2}{*}{ Construct } & \multirow[b]{2}{*}{$M$} & \multirow[b]{2}{*}{$S D$} & \multicolumn{5}{|c|}{ Correlation matrix } \\
\hline & & & 1 & 2 & 3 & 4 & 5 \\
\hline \multicolumn{8}{|l|}{ Sponsor A } \\
\hline 1. Attitudinal loyalty & 6.06 & 1.05 & 1.00 & & & & \\
\hline 2. Behavioral loyalty & 7.91(a) & 6.50 & $.38 * *$ & 1.00 & & & \\
\hline 3. Sponsorship awareness & $4.66(b)$ & 1.94 & $.08 * *$ & $.11 * *$ & 1.00 & & \\
\hline 4. Attitude toward the sponsor & 5.88 & 1.31 & $.22 * *$ & $.06^{*}$ & $.10 * *$ & 1.00 & \\
\hline 5. Purchase intentions & 5.10 & 1.93 & $.26 * *$ & $.15^{* * *}$ & $.09 * *$ & $.74 * *$ & 1.00 \\
\hline \multicolumn{8}{|l|}{ Sponsor B } \\
\hline 1. Attitudinal loyalty & 6.06 & 1.05 & 1.00 & & & & \\
\hline 2. Behavioral loyalty & $7.91^{\text {(a) }}$ & 6.50 & $.38 * *$ & 1.00 & & & \\
\hline 3. Sponsorship awareness & $4.66^{(b)}$ & 1.94 & $.08 * *$ & $.11 * *$ & 1.00 & & \\
\hline 4. Attitude toward the sponsor & 5.27 & 1.63 & $.14 * *$ & -.03 & $.10 * *$ & 1.00 & \\
\hline 5. Purchase intentions & 4.66 & 2.10 & $.17 * *$ & -.01 & $.10 * *$ & $.77 * *$ & 1.00 \\
\hline
\end{tabular}

Note. (a) Scale referring to the games attended per season and in the current season. The length in years as season-ticket holder was $3.96(S D=3.34)$; (b) Scale from 0 to 12 using the recall measure.

No correlations failed the AVE test of discriminant validity.

$* p<.05$; ** $p<.01$. 
Table 3 Summary Results of the Structural Model for Each Sponsor

\begin{tabular}{|c|c|c|c|c|c|c|}
\hline \multirow[b]{2}{*}{$\mathrm{H}$} & \multirow[b]{2}{*}{ Path } & \multirow[b]{2}{*}{ Confirmed? } & \multicolumn{2}{|c|}{ Sponsor A } & \multicolumn{2}{|c|}{ Sponsor B } \\
\hline & & & $\beta$ & Z-value & $\beta$ & Z-value \\
\hline $\mathrm{H} 1$ & Attitudinal loyalty $\AA^{\circledR}$ Behavioral loyalty & Yes & $.38 * *$ & 12.67 & $.38 * *$ & 12.67 \\
\hline $\mathrm{H}_{2} \mathrm{a}$ & Attitudinal loyalty ${ }^{\circledR}$ Sponsorship awareness & No & .04 & 1.40 & .04 & 1.40 \\
\hline $\mathrm{H} 2_{b}$ & Behavioral loyalty (B) Sponsorship awareness & Yes & $.09 * *$ & 3.51 & $.09 * *$ & 3.51 \\
\hline $\mathrm{H}_{\mathrm{a}}$ & Attitudinal loyalty $\AA^{\circledR}$ Attitude toward the sponsor & Yes & $.22 * *$ & .7 .18 & $.17 * *$ & 5.23 \\
\hline $\mathrm{H} 3_{b}$ & Behavioral loyalty $\AA$ Attitude toward the sponsor & No & -.03 & -1.25 & $-.10 * *$ & -3.74 \\
\hline $\mathrm{H} 4 \mathrm{a}$ & Attitudinal loyalty ${ }^{\circledR}$ Purchase intentions & Yes & $.08 * *$ & 3.41 & $.07 * *$ & 3.10 \\
\hline $\mathrm{H} 4_{b}$ & Behavioral loyalty $\AA^{\circledR}$ Purchase intentions & Partially & $.08 * *$ & 3.95 & -.02 & -1.09 \\
\hline H5 & Sponsorship awareness ${ }^{\circledR}$ Attitude toward the sponsor & Yes & $.09 * *$ & 3.16 & $.09 * *$ & 3.94 \\
\hline H6 & Sponsorship awareness ${ }^{\circledR}$ Purchase intentions & No & .01 & .14 & .02 & .15 \\
\hline $\mathrm{H} 7$ & Attitude toward the sponsor $\AA$ Purchase intentions & Yes & $.72 * *$ & 36.91 & $.76^{* *}$ & 43.32 \\
\hline
\end{tabular}

Note. ${ }^{*} p<.05 ; * * p<.01$.

Model fit (sponsor A): $\chi^{2}(68)=550.45(\mathrm{p}<.001), \chi^{2} / \mathrm{df}=8.01, \mathrm{TLI}=.97, \mathrm{CFI}=.98, \mathrm{GFI}=.96, \mathrm{RMSEA}=.06$.

Model fit (sponsor B): $\chi^{2}(68)=294.90(\mathrm{p}<.001), \chi^{2} / \mathrm{df}=4.34, \mathrm{TLI}=.99, \mathrm{CFI}=.99, \mathrm{GFI}=.98, \mathrm{RMSEA}=.04$.

coefficient from sponsorship awareness to purchase intentions showed a lack of significance for both sponsors $(p$ $>.05)$. Still, sponsorship awareness showed a significant indirect effect on intentions to purchase products of both Sponsor A $(\beta=.06, p<.05)$ and Sponsor $\mathrm{B}(\beta=.07$, $p<.05)$, via its impact on attitude toward each of the sponsors. Finally, attitude toward the sponsor showed a significant positive effect on purchase intentions of both Sponsor $\mathrm{A}(\beta=.72, p<.01)$ and Sponsor $\mathrm{B}(\beta=.76 ; p<$ .01) supporting H7. Jointly, attitudinal loyalty, behavioral loyalty, sponsorship awareness, and attitude toward the sponsor accounted for approximately $57 \%$ of the variance of purchase intentions regarding Sponsor $\mathrm{A}\left(R^{2}=.57\right)$ and $60 \%$ concerning Sponsor B $\left(R^{2}=.60\right)$.

In addition, the comparison between the path coefficients in the models for Sponsor A and Sponsor B is presented in Figure 2. Both the unconstrained model $\left[\chi^{2}(136)=845.35(p<.001), \chi^{2} / \mathrm{df}=6.22, \mathrm{TLI}=.98\right.$, $\mathrm{CFI}=.98, \mathrm{GFI}=.97, \mathrm{RMSEA}=.04]$ and the model constraining the structural weights to an equal value to both sponsors $\left[\chi^{2}(156)=920.98(p<.001), \chi^{2} / \mathrm{df}=5.90\right.$, $\mathrm{TLI}=.98, \mathrm{CFI}=.98, \mathrm{GFI}=.97, \mathrm{RMSEA}=.04]$ showed an acceptable fit to the data. The $\chi^{2}$ statistic indicated that these models were significantly different from one another $\left[\chi^{2} \operatorname{dif}(20)=75.62, p<.001\right]$, while the $Z$ tests for differences between structural parameters revealed that three proposed relationships differ significantly according to the sponsor. Specifically, behavioral loyalty showed a significantly different effect on the attitude toward the Sponsor A and Sponsor B $(Z=2.22 ; p<.01)$, as well as on purchase intentions $(\mathrm{Z}=3.52 ; p<.01)$. In addition, the relationship between attitude toward the Sponsor B and purchase intentions is significantly higher than for the Sponsor A $(\mathrm{Z}=4.25, p<.01)$.

\section{Discussion and Implications}

The initial goal of this study was to understand how team loyalty was related to fans' evaluation of actual team sponsors. This study extends the body of knowledge in the sport sponsorship literature by (1) exploring the role of both attitudinal and behavioral dimensions of team loyalty on sponsors' outcomes, and (2) examining the relationships between this multidimensional construct of team loyalty with sponsorship awareness, attitude toward two actual sponsors of a professional sport team, along with intentions to purchase products of those sponsors. The results obtained indicate that not all hypotheses proposed in the study were supported, and several implications for sponsorship management can be derived from these findings.

\section{Team Loyalty and Reactions to Sponsors}

The structural equation analysis revealed that attitudinal loyalty was a significant predictor of behavioral loyalty. This finding is in line with previous research (Park \& Kim, 2000) and leads us to support the notion that team loyalty is a two-dimensional construct that should capture both actual and future behaviors of the fans toward the team (Bodet \& Bernache-Assollant, 2011; Kaynak et al., 2008; Stevens \& Rosenberger, 2012). Regarding the effect of the team loyalty constructs on sponsorship awareness, attitudinal loyalty was not found to be a significant predictor of this outcome variable, while behavioral loyalty was significantly related to the awareness of both sponsors. These findings suggest that although committed fans may be more likely than the average sport consumer to become aware of the sponsors' brands (Ko et 


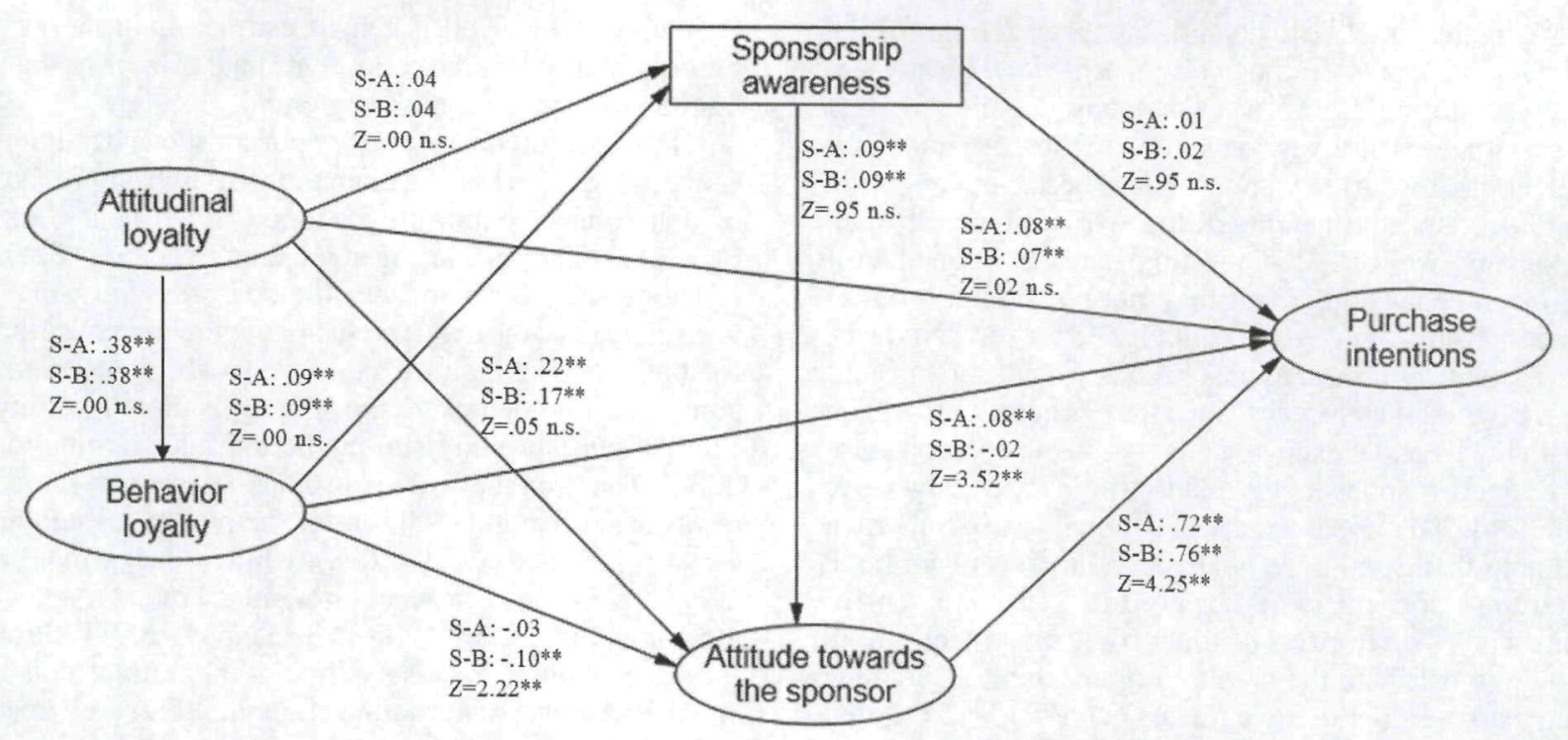

Figure 2 - Standardized estimates of the structural models. Notes: S-A = Sponsor A; S-B = Sponsor B; * $p<.05 ; * * p<.01$; n.s.=Not Significant.

al., 2008; Miloch \& Lambrecht, 2006), it is the repeated exposure to the messages during the games at the stadium that likely determines the ability to recall a brand as team sponsor. In addition, these findings highlight the role of having naming rights in the stadium stands and displaying brand's logo on team shirts (Chadwick \& Thwaites, 2004; Chen \& Zhang, 2011) since both sponsors of this study use these sponsorship activation strategies. This view is consistent with the idea that awareness increases as a function of duration to exposure (Walliser, 2003). Given this, sponsors could also design additional activities at the stadium, such as interacting with spectators through product sampling and promotional products, or engaging spectators on half-time contests concerning the sponsor (Maxwell \& Lough, 2009), to increase sponsorship recall accuracy among spectators (Wakefield \& Bennett, 2010).

The relationship between attitudinal loyalty and attitude toward the sponsor was found to be statistically significant for both sponsors. These findings support prior literature indicating that fans' attachment to a team plays a pivotal role on developing favorable dispositions toward the sponsors (Madrigal, 2001), and highlight the importance of sport fans as an attractive target group for corporations aiming to engage in sponsorship programs (Hong, 2011). However, the role of behavioral loyalty on the attitude toward the sponsor was significantly different for the two brands, highlighting the importance of examining actual sponsors rather than generic sponsors. Behavioral loyalty was not found to be a significant predictor of the attitude toward the Sponsor A, and showed a significant negative effect on attitude toward the Sponsor B. When considering that Sponsor B has sponsorship deals with other rival soccer teams, these results may suggest that if the sponsor's commitment with the team does not seem credible in the eyes of the consumer, the attitude toward the sponsor may not be influenced or even negatively affected (Dionísio, Leal, \& Moutinho, 2008; Rifon, Choi, Trimble, \& Li, 2004; Speed \& Thompson, 2000).

Another explanation may be related to the sample characteristics. A deeper analysis of the sample revealed that older fans ( 50 years or older) exhibit more established behaviors toward the team over time, and the majority of participants were already paying a membership fee to SLB before the partnership deal between the club and these sponsors. This indication is in line with anecdotal evidence suggesting that fans who support the team for a long time are more conservative about the presence of sponsors on the team shirts (Sport Business, 2011), while younger consumers tend to be more receptive to sponsorship (Rodgers, 2004). Based on these findings, corporate sponsors should actively work to demonstrate their commitment to the sport entity, while sport teams need to make clear to their followers the importance of corporate sponsors to their continued existence and sporting success (Dionísio et al., 2008; Hong, 2011). In fact, Madrigal (2001) suggested that a fan's belief that sponsorship reduces team's operating expenses may lead to a favorable attitude toward the sponsor.

The role of attitudinal loyalty was also found to be significant in predicting purchase intentions for both sponsors, supporting previous literature indicating that fans with a strong attachment to the team are likely to buy products of the sponsors (Madrigal, 2001). Thus, it could be argued that by creating and maintaining a high number of committed fans, the teams will make sponsorship 
investment attractive to potential sponsors (Hong, 2011). However, the path coefficient from behavioral loyalty was significantly different for each sponsor, indicating that behavioral loyalty was only found to predict purchase intentions toward the Sponsor A. These findings bring into question the meaningfulness of studying abstract sponsors, while also suggesting that the frequency of game attendance by itself may not be enough to influence consumer intentions to purchase sponsors' products.

Considering that Sponsor A has no sponsorship contracts with other soccer teams, these findings are in line with the idea that exclusivity is a valuable component of an effective sponsorship relationship (Deitz, Myers, \& Stafford, 2012; Henseler et al., 2011). It is also important to note that Sponsor A is an alcoholic beverage brand, and thus, consumers do not need to exert an extensive financial effort to buy the product or to make a long-term commitment with the brand. Furthermore, this brand is the market leader in its segment (Económico, 2012) and fans can buy the beverage inside the stadium and surrounding areas. On the other hand, Sponsor B is a television and internet-service provider that is not accessible during the games; meaning that the actual purchase of the sponsors' product is probably done when fans are not in the sport environment. In addition, purchasing these products is more expensive and involves a long-term contract with the firm where the consumer pays a monthly fee. That way, involvement with the sponsor's product (McDaniel, 1999), group norms (Madrigal, 2000), as well as product-category and its price may be important factors in future research to better understand fans' responses to the sponsors of their teams.

\section{Continuum of Reactions to Team Sponsors}

When examining the relationships between consumers' reactions to sponsors, a significant positive relationship between sponsorship awareness and attitude toward both sponsors was identified, supporting prior literature (Meenaghan, 2001; Schlesinger \& Güngerich, 2011). This finding suggests that the effects triggered through exposure will favor fans' attitude toward the sponsoring brands (O'Reilly et al., 2007). On the other hand, sponsorship awareness did not show a significant effect on purchase intentions toward either sponsor, but only an indirect effect via the attitude toward each sponsor. Yang et al. (2008) suggested that seeing a sponsor's name associated with sporting events, year after year, reinforces the impression of the product-sports relationship in consumers' memory. However, results from this study indicate that although fans may be aware of a great amount of team sponsors, their intentions to purchase sponsors' products will only increase if they develop a favorable attitude toward those sponsors. Recent studies suggest that celebrity endorsement leads to favorable attitudes toward the endorsed brand (Spry, Pappu, \& Cornwell, 2011; Till, Stanley, \& Priluck, 2008). Thus, if a firm sponsoring a team also engages in a deal with a team player perceived as being trustful both in sport and the community, this deal may contribute to improve fans' attitude toward the sponsoring brand.

Finally, attitude toward the sponsor showed a significant positive effect on the intentions to purchase products of that sponsor confirming previous empirical studies (Madrigal, 2001; Schlesinger \& Güngerich, 2011; Speed \& Thompson, 2000). In fact, attitude toward the sponsor was found to be the major predictor of purchase intentions for both sponsors, and is consistent with the idea that consumer attitude toward the sponsor is more meaningful than pure awareness in predicting sales (Crompton, 2004). The awareness of sponsors is a necessary but not always a sufficient condition for the purchase intention (Keller, 2008; Ko et al., 2008), while a background of sympathy toward a product or brand is crucial to generate competitive advantages (Meenaghan, 2001). Based on these findings, sponsors should help attract fans to sponsored events (Maxwell \& Lough, 2009) and create a link between the team fans and their products (e.g., exclusive products for spectators, posters of the team players using sponsor's products, discounted tickets for future games), given that sponsorship is more effective when consumers develop positive associations with the sponsoring brand (Roy \& Cornwell, 2004). This may be even more relevant for those sponsors with low levels of market share, given that the effect of attitude toward the sponsor on purchase intentions was significantly stronger for Sponsor B and this brand has about half of consumers than the market leader in its segment (Jornal de Negócios, 2011).

In summary, findings from this study indicate that attitudinal loyalty influences positively behavioral loyalty. In turn, attitudinal loyalty is not a significant predictor of sponsorship awareness, but has a positive direct effect on attitude toward both sponsors and purchase intentions of its products. Behavioral loyalty has a positive direct effect on sponsorship awareness but does not contribute positively for the attitude toward both sponsors, and only has significant positive effect on the intentions to purchase products of Sponsor A. Sponsorship awareness influences significantly the attitude toward both sponsors, but it does not have a direct effect on purchase intentions. Lastly, attitude toward the sponsor is the strongest predictor of the intentions to purchase its products. The combined effects of attitudinal loyalty, behavioral loyalty, sponsorship awareness and attitude toward the sponsor explained over half of the variance for both sponsors, highlighting the role of understanding how fans view both the team and sponsors to properly manage a sponsorship deal (Hong, 2011).

Based on these findings, professional sport teams need to work at increasing both the attitudinal and behavioral dimension of team loyalty to demonstrate sponsorship as a good strategy for sponsors, while sponsors should create a symbiotic relationship with the team and its fans to legitimize their role as a sponsor (Farrelly et al., 2005). This study also highlights the role of focusing on actual sponsors, rather than generic sponsors, given 
that the relationships between the team loyalty constructs and sponsors' outcomes differed according to each of the sponsors. Sport organizations and corporate sponsors should commit themselves to the sponsorship deal and work both within and outside the context of sponsorship to understand how to augment their linkages over time (Bühler et al., 2007).

\section{Limitations and Future Research}

While this research has provided important insights to the continued understanding of sport sponsorship, there are some limitations that should be considered for future studies. First, the context of sponsorship was limited to one professional soccer team and two of its sponsors. Thus, the findings may have been influenced by the specific characteristics of the sponsorship context and lack generalizability to sport sponsorship settings in general. Additional samples from other professional sport settings should be collected in future research to further clarify our understanding of sport sponsorship. Second, data were collected through a mail survey and it may have contributed to sample selectivity (e.g., gender). Previous research suggests that demographic characteristics can influence sponsorship effectiveness (Alexandris et al., 2008), and future research should use other research methodologies such as interviews at the stadium, to increase representativeness of the fans and investigate sponsorship effectiveness in different target groups.

Third, the psychometric properties of attitudinal loyalty suggest the need of scale refinement in future research. Although the selection of items was derived from previous literature about fan's commitment (Neale \& Funk, 2006) and behavioral intentions (Biscaia et al., 2012), one can argue that the scale was predominantly focused on future behaviors (i.e., defend, watch, attend, recommend, purchase). Thus, the inclusion of additional items pertaining to psychological commitment with stronger focus on the individual's inner attachment with the team may contribute to increase construct validity (Bauer et al., 2008; Mahony, Madrigal, \& Howard, 2000). Fourth, although previous literature suggests measuring brand awareness through both recall and recognition (Keller, 1993; Walsh et al., 2008), only the recall task was used in the final analysis because of the low correlation between both measures. In addition, the recall measure was not specifically addressed for each of the sponsors used in this study, and this might have contributed to explaining the lack of a significant direct relationship with purchase intentions. Future research should use previously established scales from the branding literature (e.g., Yoo \& Donthu, 2001) to measure the awareness of specific sponsors to better understand the role of sponsorship awareness and its subsequent outcomes. In addition, the comparison of sponsorship awareness based upon the location where fans see the games (i.e., TV versus stadium) would be an interesting topic for examining the effectiveness of sport sponsorship.
Fifth, fans' perception of team performance during the season was not controlled, and Chadwick and Thwaites (2004) suggest that sponsorship success follows the team's on-field success. Additional research could assess the fan-team-sponsor link at different points of the season to better understand how sponsorship works in the mind of sport fans. Sixth, this study considered purchase intentions as an endpoint as opposed to actual purchase behavior. Although purchase intention is commonly accepted as an ultimate variable in sponsorship studies (Crompton, 2004, Gwinner \& Bennett, 2008), future research should investigate how intentions influence actual purchase behavior. Finally, the inclusion of additional constructs proposed in the literature such as sponsor image (Alexandris et al., 2007) and team or event-sponsor fit (Deitz et al., 2012), alongside with the measures used in the current study may expand our knowledge of sponsorship evaluation models. Future studies could also focus on the antecedents of team loyalty as a means to obtain a more complete picture of how sponsor and sponsee can potentiate a win-win situation with mutual benefits for both parties.

In conclusion, the current study provides important information to aid clubs at becoming a better target to sponsors, as well as for sponsors in selecting sport properties. Findings from this study contribute to strengthening the relationships between sponsors and sport entities, as well as providing valuable implications for future negotiation of sponsorship deals. The proposed model and recommendations derived from the analysis of two actual sponsors of a team provide important cues for future research and extend our knowledge of sponsorship in professional sports setting.

\section{References}

Bola, A. (2012). Liga espanhola a melhor do mundo, Portugal em $4^{\circ}$. [Online newspaper] Retrieved 20 February 2012 from: http://www.abola.pt/nnh/ver.aspx?id=309289.

Aaker, D.A. (1996). Building strong brands. New York: The Free Press.

Ajzen, I. (1991). The theory of planned behavior. Organizational Behavior and Human Decision Processes, 50, 179-211. doi:10.1016/0749-5978(91)90020-T

Ajzen, I. (2001). Nature and operation of attitudes. Annual Review of Psychology, 52(1), 27-58. doi:10.1146/annurev. psych.52.1.27

Albarracin, D., Johnson, B.T., \& Zanna, M. (2005). The handbook of attitudes. New York: Psychology Press.

Alexandris, K., Tsaousi, E., \& James, J. (2007). Predicting sponsorship outcomes from attitudinal constructs: The case of a professional basketball event. Sport Marketing Quarterly, 16, 130-139.

Alexandris, K., Douka, S., Bakaloumi, S., \& Tsasousi, E. (2008). The influence of spectators' attitudes on sponsorship awareness: a study in three different leisure events. Managing Leisure, 13, 1-12. doi:10.1080/13606710701751351

Apostolopoulou, A., \& Papadimitriou, D. (2004). "Welcome home": motivations and objectives of the 2004 grand national Olympic sponsors. Sport Marketing Quarterly, 13, 180-192. 
Aspinall, E., Nancarrow, C., \& Stone, M. (2001). The measurement of customer retention. Journal of Targeting. Measurement and Analysis for Marketing, 10, 79-87. doi:10.1057/ palgrave.jt.5740035

Barros, C.P., \& Silvestre, A.L. (2006). An evaluation of the sponsorship of Euro 2004. International Journal of Sports Marketing \& Sponsorship, 7, 192-212.

Bauer, H.H., Stokburger-Sauer, N.E., \& Exler, S. (2008). Brand image and fan loyalty in professional sport team: A refined model and empirical assessment. Journal of Sport Management, 22, 205-226.

Banville, D., Desrosiers, P., \& Genet-Volet, Y. (2000). Translating questionnaires and inventories using a cross-cultural translation technique. Journal of Teaching in Physical Education, 19, 374-387.

Bee, C.C., \& Havitz, M.E. (2010). Exploring the relationship between involvement, fan attraction, psychological commitment and behevioural intentions in a sports spectator context. International Journal of Sports Marketing \& Sponsorship, 11, 140-157.

Biscaia, R., Correia, A., Rosado, A., Maroco, J., \& Ross, S. (2012). The effects of emotions on football spectators' satisfaction and behavioral intentions. European Sport Management Quarterly, 12, 227-242. doi:10.1080/1618 4742.2012 .679949

Bodet, G., \& Bernache-Assollant, I. (2011). Consumer loyalty in sport spectatorship services: The relationships with consumer satisfaction and team identification. Psychology and Marketing, 28, 781-802. doi:10.1002/ mar.20412

Bühler, A.W., Hefferman, T.W., \& Hewson, P.J. (2007). The soccer club-sponsor relationship: identifying the critical variables for success. International Journal of Sports Marketing \& Sponsorship, 8, 291-309.

Byrne, B.M. (2000). Structural Equation Modeling with AMOS: Basic Concepts, Applications, and Programing. Mahwah, NJ: Lawrence Erlbaum Associates.

Caruana, A. (2002). Service loyalty: The effects of service quality and the mediating role of customer satisfaction. European Journal of Marketing, 36, 811-828. doi:10.1108/03090560210430818

Chadwick, S., \& Thwaites, D. (2004). Advances in the management of sport sponsorship: fact of fiction? Evidence from a English professional soccer. Journal of General Management, 30(1), 39-60.

Chavanat, N., Martinent, G., \& Ferrand, A. (2009). Sponsor and sponsees interactions: Effects on consumers' perceptions of brand image, brand attachment, and purchase intention. Journal of Sport Management, 23, 644-670.

Chen, K.K., \& Zhang, J.J. (2011). Examining consumer attributes associated with collegiate athletic facility naming rights sponsorship: Development of a theoretical framework. Sport Management Review, 14, 103-116. doi:10.1016/j.smr.2010.10.001

Cornwall, T.B. (2008). State of the art and science in sponsorship-linked marketing. Journal of Advertising, 37(3), 41-55. doi:10.2753/JOA0091-3367370304

Cornwall, T.B., Humphreys, M.S., Maguire, A.M., Weeks, C.S., \& Tellegen, C.L. (2006). Sponsorship-linked marketing: The role of articulation in memory. The Journal of Consumer Research, 33, 312-321. doi:10.1086/508436

Cousens, L., Babiak, K., \& Bradish, C.L. (2006). Beyond sponsorship: Re-framing corporate-sport relationships. Sport Management Review, 9, 1-23. doi:10.1016/S14413523(06)70017-1
Crimmins, J., \& Horn, M. (1996). Sponsorship: From management ego to marketing success. Journal of Advertising Research, 36, 11-21.

Crompton, J.L. (2004). Conceptualization and alternate operationalization of the measurement of sponsorship effectiveness in sport. Leisure Studies, 23, 267-281. doi:10.1080/0261436042000183695

Cunningham, S., Cornwell, T.B., \& Coote, L.V. (2009). Expressing identity and shaping image: The relationship between corporate mission and corporate sponsorship. Journal of Sport Management, 23, 65-86.

Dees, W., Bennett, G., \& Villegas, J. (2008). Measuring the effectiveness of sponsorship of an intercollegiate football program. Sport Marketing Quarterly, 17, 79-89.

Deitz, G.D., Myers, S.W., \& Stafford, M.R. (2012). Understanding consumer response to sponsorship information: A resource-matching approach. Psychology and Marketing, 29, 226-239. doi:10.1002/mar.20517

Deloitte (2012a). Annual review of football finance 2012. Manchester: Sports Business Group, Deloitte.

Deloitte (2012b). Fan power - Football Money League. Manchester: Sport Business Group, Deloitte.

Dionísio, P., Leal, C., \& Moutinho, L. (2008). Fandom affiliation and tribal behaviour: A sports marketing application. Qualitative Market research. International Journal (Toronto, Ont.), 11, 17-39.

Eagly, A. H., \& Chaiken, S. (1993). The psychology of attitudes Fort Worth, TX: Harcourt Brace Jovanovich College.

Económico. (2012). "Continuarei a apoiar a Central de Cervejas". [Online newspaper] Retrieved 22 August 2012 from: http://economico.sapo.pt/noticias/continuarei-a-apoiar-acentral-de-cervejas_135710.html.

Farrelly, F., Quester, P., \& Greyser, S.A. (2005). Defending the co-branding benefits of sponsorship B2B partnerships: The case of ambush marketing. Journal of Advertising Research, 45, 339-348. doi:10.1017/S0021849905050348

Fishbein, M., \& Ajzen, I. (1975). Belief, attitude, intention and behavior: An introduction to theory and research. Reading, MA: Addison-Wesley.

Fornell, C., \& Larcker, D.F. (1981). Evaluating structural equation models with unobservable variables and measurement error. JMR, Journal of Marketing Research, 18, 39-50. doi: $10.2307 / 3151312$

Funk, D.C., \& James, J. (2001). The psychological continuum model: A conceptual framework for understanding and individual's psychological connection to sport. Sport Management Review, 4, 119-150. doi:10.1016/S14413523(01)70072-1

Guinness World Records. (2007). Guinness world records Edição especial Benfica. Lisboa: Dom Quixote. [Guinness world records - Special edition Benfica].

Gwinner, K., \& Bennett, G. (2008). The impact of brand cohesiveness and sport identification on brand fit in a sponsorship context. Journal of Sport Management, 22, 410-426.

Hair, J.F., Black, W.C., Babin, B., \& Anderson, R.E. (2009). Multivariate data analyses (7th ed.). New York: Prentice Hall.

Henseler, J., Wilson, B., \& Westberg, K. (2011). Managers' perceptions of the impact of sport sponsorship on brand equity: Which aspects of the sponsorship matter most? Sport Marketing Quarterly, 20, 7-21.

Hong, J. (2011). Sport fans' sponsorship evaluation based on their perceived relationship value with a sport property. International Journal of Sport Management and Marketing, 9, 116-131. doi:10.1504/IJSMM.2011.040260 
International Events Group (IEG). (2012). Economic uncertainity to slow sponsorship growth in 2012, January 3. Available at: http://www.sponsorship.com/iegsr/print.aspx.

Irwin, R.L., \& Asimakopoulos, M.K. (1992). An approach to the evaluation and selection of sport sponsorship proposals. Sport Marketing Quarterly, 1, 43-51.

Iwasaki, Y., \& Havitz, M.E. (2004). Examining relationships between leisure involvement and loyalty to a recreation agency. Journal of Leisure Research, 36, 45-72.

Jornal de Negócios. (2011). Meo ganha quota de Mercado na televisão por subscrição com perdas da Zon e Cabovisão. [Online newspaper] Retrieved 22 August 2012 from: http://www.jornaldenegocios.pt/home. php?template=SHOWNEWS_V2\&id=495795.

Kaynak, E., Salman, G.G., \& Tatoglu, E. (2008). An integrative framework linking brand associations and brand loyalty in professional sports. Journal of Brand Management, 15, 336-357. doi:10.1057/palgrave.bm.2550117

Keller, K.L. (1993). Conceptualizing, measuring, and managing customer-based brand equity. JMR, Journal of Marketing Research, 57, 1-22.

Keller, K.L. (2003). Brand synthesis: The multidimensionality of brand knowledge. The Journal of Consumer Research, 29, 595-600. doi:10.1086/346254

Keller, K.L. (2008). Strategic brand management: Building, measuring, and managing brand equity (3rd ed.). Upper Saddle River, NJ: Pearson Prentice Hall.

Kline, R.B. (1998). Principles and practice of structural equation modeling. New York: The Guilford Press.

Ko, Y.J., Kim, K., Claussen, C.L., \& Kim, T.H. (2008). The effects of sport involvement, sponsor awareness and corporate image on intention to purchase sponsors' products. International Journal of Sports Marketing \& Sponsorship, 9, 79-94.

Koo, G.Y., Quarterman, J., \& Flynn, L. (2006). Effect of perceived sport event and sponsor image fit on consumers' cognition, affect, and behavioural intentions. Sport Marketing Quarterly, 15, 80-90.

Kwak, D.H., Kim, Y.K., \& Hirt, E.R. (2011). Exploring the role of emotions on sport consumers' behavioral and cognitive responses to marketing stimuli. European Sport Management Quarterly, 11, 225-250. doi:10.1080/1618 4742.2011.577792

Lee, S., Harris, J., \& Lyberger, M. (2011). Recreational golfers' attitudes and awareness of sponsorship: a case study of the 2008 Ryder Cup. Managing Leisure, 16, 192-206. doi:10 $.1080 / 13606719.2011 .583407$

Loehlin, J.C. (2003). Latent variable models: An introduction to factor, path, and structural equation analysis (4th ed.). Mahwah, NJ: Lawrence Erlbaum Associates.

Madrigal, R. (2000). The influence of social alliances with sports teams on intentions to purchase corporate sponsors' products. Journal of Advertising, 29(4), 13-24.

Madrigal, R. (2001). Social identity effects in a belief-attitudeintentions hierarchy: Implications for corporate sponsors. Psychology and Marketing, 18, 145-165. doi:10.1002/15206793(200102)18:2<145::AID-MAR1003>3.0.CO;2-T

Madrigal, R. (2003). Investigating an evolving leisure experience: Antecedents and consequences of spectator affect during a live sporting event. Journal of Leisure Research, $35,23-48$.

Mahony, D.F., Madrigal, R., \& Howard, D. (2000). Using the psychological commitment to team (PCT) scale to segment sport consumers based on loyalty. Sport Marketing Quarterly, 9, 15-25.
Maxwell, H., \& Lough, N. (2009). Signage vs. No signage: An analysis of sponsorship recognition in women's college basketball. Sport Marketing Quarterly, 18, 188-198.

McDaniel, S.R. (1999). An investigation of match-up effects in sport sponsorship advertising: The implications of consumer advertising schemas. Psychology and Marketing, 16, 385-403. doi:10.1002/(SICI)15206793(199903)16:2<163::AID-MAR6>3.0.CO;2-Y

Meenaghan, T. (1991). The role of sponsorship in the marketing communications mix. International Journal of Advertising, 22, 35-48.

Meenaghan, T. (2001). Understanding sponsorship effects. Psychology and Marketing, 18, 95-122. doi:10.1002/15206793(200102)18:2<95::AID-MAR1001>3.0.CO;2-H

Miloch, K.S., \& Lambrecht, K.W. (2006). Consumer awareness of sponsorship at grassroots sport events. Sport Marketing Quarterly, 15, 147-154.

Neale, L., \& Funk, D. (2006). Investigating motivation, attitudinal loyalty and attendance behavior with fans of Australian football. International Journal of Sports Marketing \& Sponsorship, 7, 307-317.

Oliver, R.L. (1997). Satisfaction: A behavioral perspective on the consumer. New York: McGraw-Hill.

O'Reilly, N., Nadeau, J., Séguin, B., \& Harrison, M. (2007). In-stadium sponsorship evaluation of a mega-sponsee: The 2004 Grey Cup. International Journal of Sports Marketing \& Sponsorship, 8, 179-198.

Park, S., \& Kim, Y. (2000). Conceptualizing and measuring the attitudinal construct in recreational sport contexts. Journal of Sport Management, 14, 197-207.

Parker, H.M., \& Fink, J.S. (2010). Negative sponsor behaviour, team response and how this impacts fans attitudes. International Journal of Sports Marketing \& Sponsorship, $11,200-211$.

Rifon, N.J., Choi, S.M., Trimble, C.S., \& Li, H. (2004). Congruence effects in sponsorship. Journal of Advertising, 33(1), 29-42. doi:10.1080/00913367.2004.10639151

Rodgers, S. (2004). The effects of sponsor relevance on consumer reactions to iinternet sponsorship. Journal of Advertising, 32(4), 67-76. doi:10.1080/00913367.2003 .10639141

Roy, D.P., \& Cornwell, T.B. (2004). The effect of consumer knowledge on responses to event sponsorships. Psychology and Marketing, 21, 185-207. doi:10.1002/mar.20001

Santomier, J. (2008). New media, branding and global sports sponsorship. International Journal of Sports Marketing \& Sponsorship, 10, 15-28.

Schlesinger, T., \& Güngerich, M. (2011). Analysing sport sponsorship effectiveness - the influence of fan identification credibility and product-involvement. International Journal of Sport Management and Marketing, 9, 54-74. doi:10.1504/IJSMM.2011.040257

Shank, M.D., \& Beasley, F.M. (1998). Fan or fanatic: refining a measure of sports involvement. Journal of Sport Behavior, 21, 435-443.

Shaw, R.N., \& McDonald, H. (2006). Season-ticket holder satisfaction and sponsor-related behaviour: evidence of positive relationship. International Journal of Sports Marketing \& Sponsorship, 7, 318-325.

Spears, N., \& Singh, S.N. (2004). Measuring attitude toward the brand and purchase intentions. Journal of Current Issues and Research in Advertising, 26(2), 53-66. doi:10.1080/ 10641734.2004.10505164 
Speed, R., \& Thompson, P. (2000). Determinants of sports sponsorship response. Journal of the Academy of Marketing Science, 28, 226-238. doi:10.1177/0092070300282004

Sport Business. (2011). Barcelona members give green light to Qatar Foundation sponsorship. [Web page information] Retrieved 13 September 2012 from: http://www.sportbusiness.com/news/184379/barcelona-members-give-greenlight-to-qatar-foundation-sponsorship.

Spry, A., Pappu, R., \& Cornwell, T.B. (2011). Celebrity endorsement, brand credibility and brand equity. European Journal of Marketing, 45, 882-909. doi:10.1108/03090561111119958

Stevens, S., \& Rosenberger, P.J. (2012). The influence of fan involvement, following sport and fan identification on fan loyalty: An Australian perspective. International Journal of Sports Marketing \& Sponsorship, 13, 220-234.

Stotlar, D.K. (1993). Sponsorship and the Olympic winter games. Sport Marketing Quarterly, 2, 35-43.

Theodorakis, N., Wann, D.L., \& Weaver, S. (2012). An antecedent model of team identification in the context of professional soccer. Sport Marketing Quarterly, 21, 80-90.

Till, B.D., Stanley, S.M., \& Priluck, R. (2008). Classical conditioning and celebrity endorsers: An examination of belongingness and resistance to extinction. Psychology and Marketing, 25, 173-176. doi:10.1002/mar.20205
Wakefield, K., \& Bennett, G. (2010). Affective intensity and sponsor identification. Journal of Advertising, 39(3), 99-111. doi:10.2753/JOA0091-3367390307

Walliser, B. (2003). An international review of sponsorship research: extension and update. International Journal of Advertising, 22, 5-40.

Walsh, P., Kim, Y., \& Ross, S. (2008). Brand recall and recognition: A comparison of television and sport video games as presentation modes. Sport Marketing Quarterly, 17, 201-208.

Wann, D.L., Melnick, M.J., Russell, G.W., \& Pease, D.G. (2001). Sport fans: The psychology and social impact of spectators. New York: Routledge Press.

Wilkie, W.L. (1994). Consumer behavior. New York: John Wiley and Sons.

Yang, X.S., Sparks, R., \& Li, M. (2008). Sport sponsorship as a strategic investment in China: perceived risks and benefits by corporate sponsors prior to Beijing 2008 Olympics. International Journal of Sports Marketing \& Sponsorship, 10, 63-78.

Yoo, B., \& Donthu, N. (2001). Developing and validating a multidimensional consumer-based brand equity scale. Journal of Business Research, 52, 1-14. doi:10.1016/ S0148-2963(99)00098-3 
Copyright of Journal of Sport Management is the property of Human Kinetics Publishers, Inc. and its content may not be copied or emailed to multiple sites or posted to a listserv without the copyright holder's express written permission. However, users may print, download, or email articles for individual use. 